\title{
Development of Interactive Physics Learning Media Using Smartphone Integrated with Pancasila Values on Optical Instrument
}

\author{
Syarifah Aini Nabila ${ }^{1, *}$ Ariswan $^{2,}$ Erlita Agustina $^{1,}$ Nurhasanah $^{1}$ \\ ${ }^{1}$ Master of Physics Education, Faculty of Mathematics and Natural Science, Universitas Negeri Yogyakarta, \\ Indonesia \\ ${ }^{2}$ Department of Physics Education, Faculty of Mathematics and Natural Science, Universitas Negeri Yogyakarta, \\ Indonesia \\ ${ }^{*}$ Corresponding author. Email: syarifahaini.2019@student.uny.ac.id
}

\begin{abstract}
This study purpose to determine the feasibility of an interactive learning media using a smartphone on the integrated optical instrument of Pancasila values. The type of research used is Research and Development with a 4-D model, namely Define, Design, Development, and Disseminate. The research subjects were students of class XI IPA 3 at SMA N 1 Prambanan Yogyakarta in the 2019/2020 school year. The research subjects were 24 students. Data were gathered through observation data collection techniques, interviews with physics teachers as well as interviewing several students, and student response questionnaire. The data collected were analysed using descriptive analysis. The results are that the interactive physics learing media using smartphone integrated with the Pancasila value is suitable for use in the learning process based on expert validation (material and media), and practitioner. Student responses to the media are very good.
\end{abstract}

Keywords: Interactive physics learning media, Pancasila values, Physics learning

\section{INTRODUCTION}

The era of the industrial revolution always undergoes changes due to technological developments. At this time we are entering the era of the 4.0 industrial revolution which has changed the way humans work into automation and digitization [1]. These changes are intended so that in the era of the industrial revolution 4.0 humans are able to increase productivity and flexibility [2]. The changes that occurred in the revolutionary era 4.0 had a good effect on various things, that is economy, social, technology, health and education. [3]. What can be felt by the rapid changes and developments in technology during the revolutionary era 4.0 is the easier access to information from various sources [4]. The implementation of technology in education is the creation of various platforms as learning media, learning resources, and administrative tools [5]. Technology and education can combine to improve the quality of learning in schools [6].

Improving the quality of learning in schools through the curriculum, learning methods and interactive learning media with the help of developing technology. Technologies that can be used such as computers, communication tools, and television are used as instruments in the learning process [7]. One of the technologies that can be used in the learning process is a smartphone. Smartphones are used as an alternative as a tool for interactive learning media in the era of the industrial revolution of 4.0 [8]. The selection of smartphones as a tool in learning media is because on average students in Indonesia already have smartphones and the use of smartphones can also divert negative effects on students during the learning process such as playing games that are not related to learning material [9]. Another reason for choosing smartphones is because these objects are not foreign goods, especially for students in Indonesia and in general students are more interested in reading and socializing using smartphones [10].

The use of interactive learning media for students is to increase understanding of concepts (learning materials and practice questions) and increase creativity in students. Interactive learning media is 
very important for students because interactive learning media has the advantage of being able to interact more broadly [11]. The presence of learning media by using smartphones is used as a complement to learning and provides opportunities for students to access learning without the time and place limits so that the learning process can be carried out both faceto-face and distance learning [12][13]. Platforms that can facilitate both distance and face-to-face learning are social media which includes wikis, blogs, discussion forums, virtual worlds, content communities, and online games [14]. Various technologies and platforms can create various learning media that can be used during the learning process [15]. Technology that creates various learning media that can support students' learning abilities and provide opportunities for students to be more active in the learning process so that the learning process becomes more interactive and interesting for students.

The use of interactive learning media can be applied to every subject, including learning physics. Given that abstract physics learning is full of concepts, facts, principles, and generalizations, so students think that physical learning is not interesting and difficult to understand [16]. Difficulty in understanding physics learning and disinterest in physical learning is caused by the teaching method used by the teacher, namely the lecture method which allows students to be passive in the learning process and less supportive infrastructure such as less varied learning media [12][16]. The lack of variation in instructional media is due to the fact that teachers experience problems with the use of technology [12]. Overcoming these problems, teachers are required to have the ability to use technology which aims to make teachers able to modify or develop learning media to be attractive so as to foster motivation and curiosity of students [17].

Another challenge for teachers is building the character of students based on the values of Pancasila as stated in Law No. 20 of 2003 [18]. The importance of instilling Pancasila values in students is because the era of the 4.0 revolution, the condition of the Indonesian nation showed bad behavior and waning cultural values of the Indonesian nation. Bad behavior such as drinking, brawls between students, criminal cases, immoral cases, acts of vandalism and so on [19]. The characters of students are not good, such as tend to be selfish, do not like to work together, do not respect parents and teachers, are trapped in bad social environments such as drugs and criminals, and retreated interest in learning in students [10]. This bad behavior shows that the Indonesian nation is experiencing a character crisis.
The importance of fostering good character for students so that Indonesia has a nation with dignity and good character in accordance with the values of Pancasila [20]. Cultivating characters in accordance with the values of Pancasila by integrating character education with physics learning [21]. However, not all characters can be applied to physics learning, but physics learning can contribute to building some good characters for students [22]. In fact, there are still teachers who think that character education is two things that cannot be combined [21]. The opinion that states that character education is something that cannot be combined must be eliminated because character education is the duty of all teachers

The need for innovation in the learning process both from learning materials and learning media that is integrated into the values of Pancasila so that it is hoped that the formation of good characters in students and the realization of the goals of Indonesian education in accordance with Law No. 23 of 2003 that education does not only emphasize the cognitive abilities of students only but can form the good character for students.

\section{RESEARCH METHOD}

The research was conducted at SMA Negeri 1 Prambanan, Yogyakarta. The sample consisted of 24 students in class XI IPA 3 in the 2019/2020 academic year with physics material, namely optical tools. The learning was carried out online due to the Covid-19 epidemic. The learning process platform with the help of social media, namely WhatsApp Group.

\subsection{Type of Research}

The type of research is Research and Development (RnD) with a 4-D model, namely Define, Design, Development, and Disseminate. The steps to develop the media, namely define the stage, at this stage observations are made to the school. Observations made in the form of analysis of the curriculum used, analysis of the learning process, analysis of the character of students both during the learning process and during breaks, and analysis of school conditions. The purpose of doing this action at the define stage is to find out the type of learning media that is suitable for students to achieve learning objectives.

The design stage, which is at this stage, selects learning media that is appropriate to the needs of students and prepares strategies for delivering learning materials that are useful for achieving the expected goals and results. The development stage is at this stage using validation steps from an expert (material 
and media), and validation from practitioner. Validation of material and media an expert, namely lecturers at Yogyakarta State University and for practitioner validation from physics teachers at SMA Negeri 1 Prambanan

\subsection{Research Instrument}

The instruments used were validation sheets by an expert (media and material), validation from practitioner and questionnaire for student responses to the media. The purpose of validation is to determine the feasibility of a product.

\subsection{Research Instrument}

The data analysis technique used is the descriptive analysis by calculating number of percentage scores from the validation by an expert (material and media), and student responses. Data analysis was performed using a formula (1) [12]

$$
\text { Percentage }=\frac{\text { Score obtained }}{\text { Maximum score }} \times 100 \%
$$

The feasibility level of the media developed is based on the percentage of scores obtained. If the percentage of scores obtained is higher, the better the feasibility of the media being developed. The criteria for the level of media validation are shown in Table 1 [12].

Table 1. Feasibility criteria

\begin{tabular}{|l|l|}
\hline Percentage (\%) & Category \\
\hline $80,00-100$ & Very Good \\
\hline $60,00-79,99$ & Good \\
\hline $50,00-59,99$ & Less Good \\
\hline $00,00-49,99$ & Not Good \\
\hline
\end{tabular}

\section{RESULTS AND DISCUSSION}

\subsection{Define Stage}

Observations and interviews were carried out before Covid-19 was in Indonesia. The results of the analysis of the curriculum show that teachers have followed the curriculum set by the government, namely the 2013 Curriculum. The results of the analysis of the environmental conditions of the school at SMA Negeri 1 Prambanan have been very good. The condition of a good school environment is one of the factors that affect the potential growth of each student [23]

The results of the analysis of the learning process in schools show that the learning process is less able to attract the attention of students because students are not directly involved in the learning process and do not use media in learning The results of the character analysis of students show that there are students who have bad character traits such as not paying attention to the teacher who is explaining the learning material. Students focus on smartphones that are not related to learning physics. The goal is to study needs analysis (curriculum, school environmental conditions, learning process, and student character) to see the problems that are the basic references in product development, the need to develop products, and solutions to problems.

Needs assessment (curriculum, school environmental conditions, learning process, and student character) is used to obtain information that will be used in media development [12] [24]. Information can be in the form of problems that become references in product development. The solution to this problem is by developing learning media, namely interactive media using smartphones. The use of smartphones aims to make students motivated and interactive when learning physics. Interactive media using smartphones is integrated with Pancasila values. The purpose of integrating Pancasila values is to develop good character in students according to the function of education according to UU No. 20 of 2003, namely to develop and shape the character of the Indonesian nation. Support from research [25] states that the importance of developing learning media that can be realized in real terms because the use of instructional media is very influential on students' motivation, interests and learning outcomes

\subsection{Design Stage}

Interactive media using a smartphone integrated with Pancasila values was created with the help of the Microsoft PowerPoint program for the manufacture of optical instrument materials. Creation of applications for learning media with the help of software, namely Ispring and APK Build so that the media can be operated on the smartphone of teachers and students.

The interactive media design integrated with the values of Pancasila has components, namely 1) cover media, 2) home page which consists of: 1) core competencies and basic competencies, 2) practicing 
Pancasila values, 3) learning materials, 4) quizzes, 5) learning media developer profile.

\subsection{Development Stage}

At the development stage that the learning media has been validated by an expert and practitioner. The product display of integrated interactive media with Pancasila values is shown in Figure 1, Figure 2, and Figure 3.

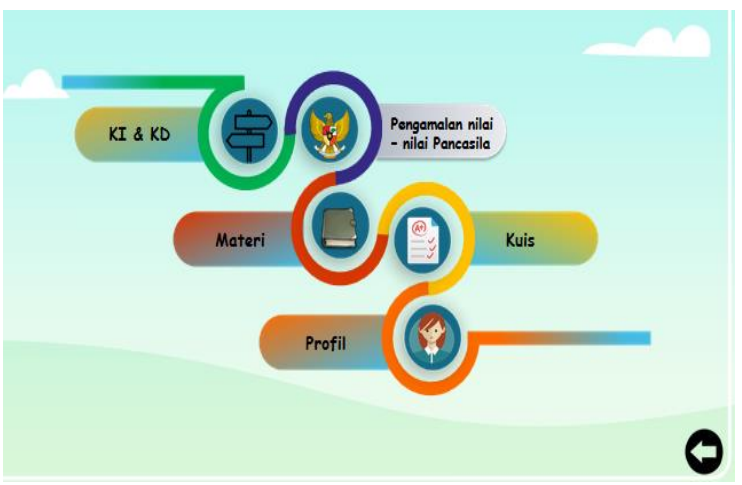

Figure 1. Home Page of interactive media using a smartphone integrated with Pancasila values.

Figure 1 shows the home page on interactive learning media using an integrated smartphone, the values of Pancasila consist of 5 parts, namely: 1) KI (Core Competency) and KD (Basic Competence) which are in accordance with Curriculum 2013, 2) practicing the value of Pancasila , 3) learning materials, 4) quizzes, 5) profile.

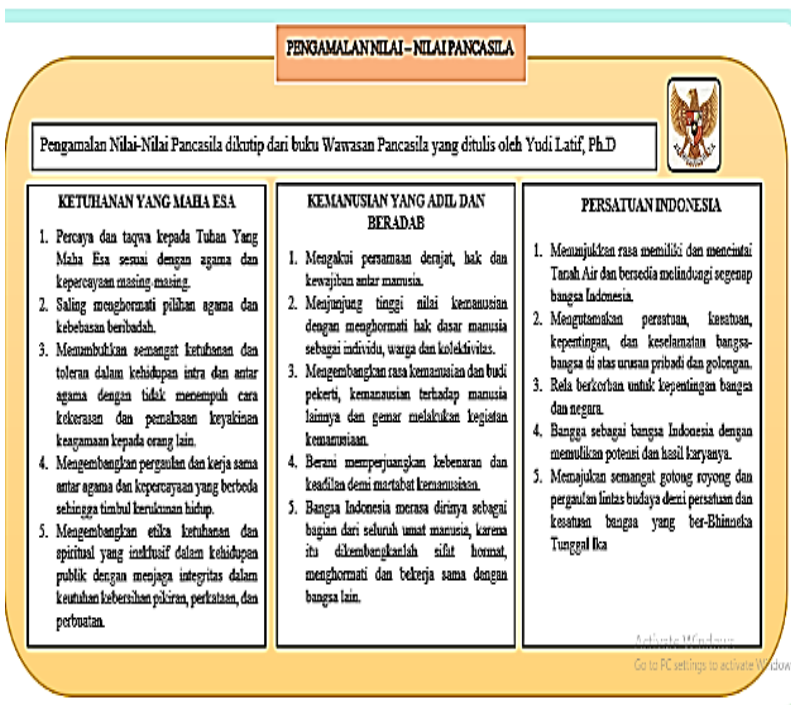

Figure 2. Practicing the values of Pancasila.
Figure 2 shows the experience of each Pancasila precept. Pancasila consists of 5 principles, that is 1) belief in the one and only God, 2) just and civilized humanity, 3) the unity of Indonesia, 4) democracy guided by the inner wisdom in the unanimity arising out deliberations amongst representatives, 5) social justice for all Indonesian people. Each of these principles contains points of experience from Pancasila that can be applied in the life of the Indonesian nation.

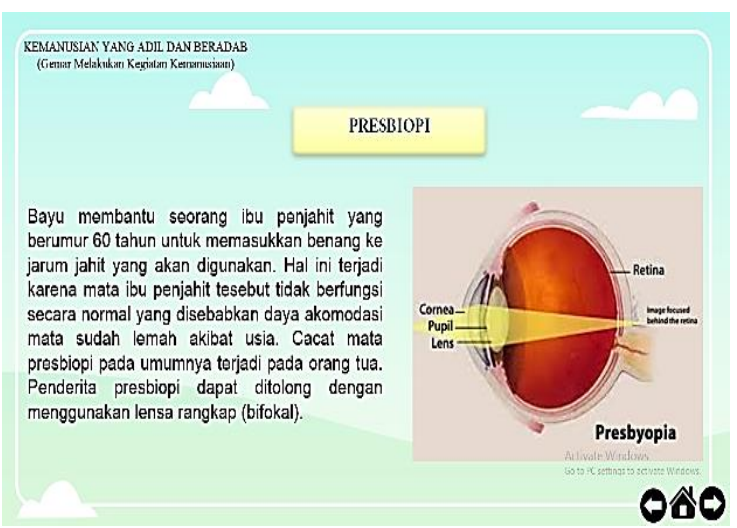

Figure 3. The practice of one of the Pancasila value, namely a just and civilized human being.

Figure 3 shows the practice of one of the values of Pancasila in optical instrument material regarding eye defects, namely presbyopia. An example used in the application of Pancasila to learning materials is Budi helping a 60 -year-old tailor to insert the thread into a sewing machine. The mother could not see the threads because she had presbyopia. Actions taken by Budi are actions related to humanitarian activities. Humanitarian action is an application of Pancasila to the second principle, namely a just and civilized humanity.

\subsubsection{Validation of Media by An Expert (Material and Media)}

Validation was carried out by one expert as an expert (material \& media). Expert is a lecture from Yogyakarta State University. The assessment carried out for the validity of the material has three components of assessment, that is; (1) content media, (2) language and image, (3) presentation. The assessment for media an expert has one aspect that is graphic. The validity results for material and media an expert are in Table 2. 
Table 2. The validity of interactive learning media by experts

\begin{tabular}{|c|c|c|c|}
\hline Expert & Components & $\begin{array}{c}\text { Percentage } \\
(\%)\end{array}$ & Category \\
\hline \multirow[t]{3}{*}{ Material } & $\begin{array}{l}\text { Content } \\
\text { Media }\end{array}$ & 83,33 & Very Good \\
\hline & $\begin{array}{l}\text { Language } \\
\text { and Image }\end{array}$ & 82,14 & Very Good \\
\hline & Presentation & 75,00 & Good \\
\hline Media & Graphics & 96,88 & Very Good \\
\hline
\end{tabular}

The validation results show that the graphic component has a higher percentage ranking than other three components, while the lowest percentage is in the presentation aspect. Weaknesses in the presentation aspect have been corrected based on media and material an expert, namely: (1) Adding Core Competencies (KI) and Basic Competencies (KD) to learning media, (2) Adding the practice of Pancasila values to the media and learning materials developed, (3) The questions are adjusted to the indicators of learning objectives.

There are also aspects of language and image that have been corrected according to the advice of material and media an expert. The drawback is the correction of errors in writing words. The results of media validation and material on interactive learning media can be declared feasible to be applied in learning with "Good and Very Good category. This result is supported by research [26] which states that character-based interactive multimedia development in physics learning is feasible to use. The use of interactive media can hone cognitive abilities, motivation and foster character values in accordance with the identity of the Indonesian nation.

\subsubsection{Validation of Media by Practitioner}

Practitioner validation by one physics teacher at SMA Negeri 1 Prambanan. The results of product development validation were assessed by practitioner. The assessment consists of four components, namely; (1) content media, (2) language and image, (3) presentation, and (4) graphics. The results of the validity by practitioner in Table 3 .
Table 3. Assessment results from practitioner for learning media

\begin{tabular}{|l|c|c|}
\hline Components & $\begin{array}{c}\text { Percentage } \\
(\%)\end{array}$ & Category \\
\hline Content Media & 86,11 & Very Good \\
\hline $\begin{array}{l}\text { Language and } \\
\text { Image }\end{array}$ & 89,28 & Very Good \\
\hline Presentation & 84,00 & Very Good \\
\hline Graphics & 87,50 & Very Good \\
\hline
\end{tabular}

The result shows that the components that has the highest percentage is language and images, while the lowest percentage of the four aspects is the presentation aspect. The deficiencies that exist in the presentation aspect have been corrected based on suggestions from practitioner, namely the increasing number of practice questions for the application of Pancasila values for students. Validation assessments by practitioner regarding the content of the material and media being developed are declared suitable for use in learning activities with the "Very Good" category. These results are supported by research [27] that prezi interactive learning media to foster the character of students 'desire to know is declared feasible and valid to foster the character of students' curiosity. The use of this learning media can also foster a good learning relationship between teachers and students.

\subsection{3.. Student Responses to Interactive} Learning Media Using A Smartphone Integrated with Pancasila Values

Table 4. Student responses for learning media

\begin{tabular}{|l|c|l|}
\hline Components & $\begin{array}{c}\text { Percentag } \\
\text { e } \\
(\%)\end{array}$ & Category \\
\hline Content Media & 87,76 & Very Good \\
\hline Language & 86,46 & Very Good \\
\hline Format Media & 87,15 & Very Good \\
\hline
\end{tabular}

Students are given a questionnaire after the learning material has been taught via a google form. Student responses use a questionnaire that aims at student responses to the learning media developed. There are three components, namely; (1) the content 
on the learning media, (2) the language used in the media, and (3) the format on the media. The results of student responses to the media developed can be seen in the Table 4.

Student responses show that the media content component reaches the highest proportion of more than $80 \%$. Two, namely the language and format components which received a low portion for the content component, even though the three components were above the percentage of $80 \%$. This percentage shows that the media obtained is the "Very Good" category. Research by researchers [28] show that the physics learning media using photonovela and character education is appropriate and students' responses were very good.

\section{CONCLUSION}

The results of validation by an expert and practitioner state that media are feasible to be applied in learning process with categories obtained from an expert (material and media) were "good" and "very good", the categories obtained from practitioner were "very good", and the students' responses to the media were "very good".

\section{REFERENCES}

[1] H. Suwardana, Revolusi Industri 4.0 Berbasis Revolusi Mental, Jurnal Ilmiah Teknik dan Manajemen Industri 1(2) (2018) 109-118. DOI: https://doi.org/10.30737/jatiunik.v1i2.117

[2] S.V. Buer, J.O. Strandhagen, F.T.S. Chan, The Link Between Industry 4.0 and Lean Manufacturing: Mapping Current Research and Establishing A Research Agenda, International Journal of Production Research 56(8) (2018) 2924-2940.

DOI: https://doi.org/10.1080/00207543.2018.1442945

[3] H.Ç. Bal, Ç. Erkan, Industry 4.0 and competitiveness, Procedia Computer Science, vol. 158, Elsevier B.V, Amsterdam, 2019, pp. 625-631.

DOI: https://doi.org/10.1016/j.procs.2019.09.096

[4] H. Budiman, Peran Teknologi Informasi dan Komunikasi dalam Pendidikan, Jurnal Pendidikan Islam 8(1) (2017) 31-43. DOI: https://doi.org/10.24042/atjpi.v8i1.2095

[5] S. Lestari, Peran Teknologi dalam Pendidikan di Era Globalisasi, Jurnal Pendidikan Agama Islam
2(2) (2018) 94-100. DOI: https://doi.org/10.33650/edureligia.v2i2.459

[6] K.H. Sugiyarto, J. Ikhsan, I.R. Lukman, The Use of An Android-Based-Game in The Team Assisted Individualization to Improve Students' Creativity and Cognitive Achievement in Chemistry, Journal of Physics: Conference Series, vol 1022, IOP Publishing, Bristol, 2018. DOI: $\quad$ https://doi.org/10.1088/1742$\underline{6596 / 1022 / 1 / 012037}$

[7] R. Hu, Y.Y. Wu, C.J. Shieh, Effects of Virtual Reality Integrated Creative Thinking Instruction on Students' Creative Thinking Abilities, Eurasia Journal of Mathematics, Science and Technology Education 12(3) (2016) 477-486. DOI: https://doi.org/10.12973/eurasia.2016.1226a

[8] Darmaji, D.A. Kurniawan, A. Astalini, A. Lumbantoruan, S.C. Samosir, Mobile Learning in Higher Education for The Industrial Revolution 4.0: Perception and Response of Physics Practicum, International Journal of Interactive Mobile Technologies 13(9) 2019 420.

DOI:

https://doi.org/10.3991/ijim.v13i09.10948

[9] I.A.D. Astuti, Dasmo, R.A. Sumarni, Pengembangan Media Pembelajaran Berbasis Android dengan Menggunakan Aplikasi Appypie di SMK Bina Mandiri Depok, Jurnal Pengabdian Kepada Masyarakat 24(2) (2018) 695-701.

DOI: https://doi.org/10.24114/jpkm.v24i2.10525

[10] Diplan, Tantangan Pendidik di Era Digital, Jurnal Pendidikan 14(2) (2019) 41-47. DOI: https://doi.org/10.33654/jpl.v14i2.888

[11] Mustika, E.P.A. Sugara, M. Pratiwi, Pengembangan Media Pembelajaran Interaktif dengan Menggunakan Metode Multimedia Development Life Cycle, Jurnal Online Informatika 2(2) (2017) 121-126. DOI: https://doi.org/10.15575/join.v2i2.139

[12] I.A.D. Astuti, R.A. Sumarni, D.L. Saraswati, Pengembangan Media Pembelajaran Fisika Mobile Learning berbasis Android, Jurnal Penelitian dan Pengembangan Pendidikan Fisika 3(1) (2017). DOI: https://doi.org/10.21009/1.03108

[13] M. Özüdoğru, M. Aksu, Pre-Service Teachers' Achievement and Perceptions of The Classroom Environment in Flipped Learning and 
Traditional Instruction Classes, Australasian Journal of Educational Technology 36(4) (2020) 27-43. DOI: https://doi.org/10.14742/ajet.5115

[14] J. Sleeman, C. Lang, E. Dakich, Social Media, Learning and Connections for International Students: The Disconnect between What Students Use and The Tools Learning Management Systems Offer, Australasian Journal of Educational Technology 36(4) (2020) 44-56. DOI: https://doi.org/10.14742/ajet.4384.

[15] R.N. Chasanah, Mujasam, S.W. Widyaningsih, I. Yusuf, Influence of The Use of Interactive Learning Media on Students' Higher Order Thinking Skills, Kasuari Physics Education Journal 2(1) (2019) 26-35. DOI: https://doi.org/10.37891/kpej.v2i1.91

[16] H. Yuliani, Mariati, R. Yulianti, C. Herianto, Keterampilan Berpikir Kreatif pada Siswa Sekolah Menengah di Palangka Raya Menggunakan Pendekatan Saintifik, Jurnal Pendidikan Fisika dan Keilmuan 3(1) (2017) 4856.

DOI:

https://doi.org/10.25273/jpfk.v3i1.1134

[17] R.D.F.D. Kusuma, S.P. Nasution, B.S. Anggoro, Multimedia Pembelajaran Matematika Interaktif Berbasis Komputer, Jurnal Matematika 1(2) (2018) 191-199. DOI: https://doi.org/10.24042/djm.v1i2.2557

[18] H.E. Siagian, N. Bukit, Derlina, The Effect of Inquiry Training Learning Model Using Macromedia Flash and Creative Thinking Ability on Science Process Skills of Student, Jurnal Pendidikan Fisika 5(1) (2016) 18-25. DOI: https://doi.org/10.22611/jpf.v5i1.3701

[19] L.P.S. Antari, L. De Liska, Implementasi Nilai Nilai Pancasila dalam Penguatan Karakter Bangsa, Widyadari Jurnal Pendidikan 21(2) (2020) 676-687. DOI: https://doi.org/10.5281/zenodo.4049444

[20] A. Adibatin, Pendidikan Karakter Bangsa Berbasis Strategi Pembelajaran Pakem melalui Permainan Cincin di Jempol Tangan (Karya Inovasi Pembelajaran Sekolah Dasar), Jurnal Pendidikan dan Kebudayaan 6(1) (2016) 1-18. DOI:

https://doi.org/10.24246/j.scholaria.2016.v6.i1.p $\underline{1-18}$

[21] I. Safitri, L.R. Hasibuan, The Character Education through Analogy Learning
Implementation on Vector Concepts, Jurnal Penelitian dan Pengembangan Pendidikan Fisika 4(2) (2018) 75-82. DOI: https://doi.org/10.21009/1.04204

[22] W. Liliawati, T. Ramlan, J.A. Utama, A.M.Z, Desain Bahan Ajar Fisika dalam Jaringan (Daring) Berorientasi Pendidikan Karakter untuk Siswa SMA, Jurnal Inovasi dan Pembelajaran Fisika 6(2) (2019) 113-121. DOI: https://doi.org/10.36706/jipf.v6i2.9856

[23] N. Putriana, R. Moslihat, Pengaruh Lingkungan Keluarga dan Lingkungan Sekolah terhadap Prestasi Belajar Siswa pada Mata Pelajaran Akuntansi di Kelas XI IPS SMA Pasundan 8 Bandung, Jurnal Pendidikan Akuntansi dan Keuangan 3(1) (2015) 13-24. DOI: https://doi.org/10.17509/jpak.v3i1.15383.

[24] R. Masykur, Nofrizal, M. Syazali, Pengembangan Media Pembelajaran Matematika dengan Macromedia Flash, Jurnal Pendidikan Matematika 8(2) (2017) 177-186. DOI: https://doi.org/10.24042/ajpm.v8i2.2014.

[25] A. Widyawati, A.K. Prodjosantoso, Pengembangan Media Komik IPA untuk Meningkatkan Motivasi Belajar dan Karakter Peserta Didik SMP, Jurnal Inovasi Pendidikan IPA 1(1) (2015) 24-25. DOI: https://doi.org/10.21831/jipi.v1i1.4529

[26] J. Syahbrudin, Multimedia Interaktif Berbasis Karakter sebagai Upaya Peningkatan Nilai-Nilai Karakter dan Kemampuan Berpikir Tingkat Tinggi, Journal of Computer Engineering, System and Science 3(1) (2018) 7-13. DOI: https://doi.org/10.24114/cess.v3i1.8322

[27] T. Solehudin, R. Triwoelandari, A.M. Kosim, Pengembangan Media Pembelajaran Interaktif Prezi untuk Menumbuhkan Karakter Rasa Ingin Tahu, Indonesian Journal of Learning Education and Counseling 2(2) (2020) 163-171. DOI: https://doi.org/10.31960/ijolec.v2i2.261

[28] F. Ariyani, T. Nayana, A. Saregar, Yuberti, A. Pricilia, Development of Photonovela with Character Education: As an Alternative of Physics Learning Media, Jurnal Ilmu Pendidikan Fisika Al-Biruni 7(2) (2018) 227-237. DOI: https://doi.org/10.24042/jipfalbiruni.v7i2.3072. 